\title{
Analisis Sebaran Penelitian Skripsi Mahasiswa Program Studi Pendidikan Matematika Universitas Muhammadiyah Mataram
}

\author{
Dewi Pramita \\ Pendidikan Matematika, Universitas Muhammadiyah Mataram, mitha dhewi@yahoo.com
}

\begin{tabular}{l} 
INFO ARTIKEL \\
\hline RiwayatArtikel: \\
Diterima: $04-03-2017$ \\
Disetujui: $02-04-2017$
\end{tabular}

\section{Kata Kunci:}

Jenis Penelitian, Tema Popular, Kesulitan, Menyusun Skripsi

\begin{abstract}
ABSTRAK
Abstrak: Penelitian ini bertujuan untuk mendeskripsikan sebaran jenis penelitian, tema yang popular serta kesulitan yang dihadapi mahasiswa dalam menyelesaikan atau menyusun skripsi program studi Pendidikan Matematika Universitas Muhammadiyah Mataram. Manfaat dari penelitian ini yaitu 1) diperoleh informasi tentang sebaran jenis penelitian dan tema penelitian yang paling sering atau paling banyak diambil oleh mahasiswa program studi Pendidikan Matematika Universitas Muhammadiyah Mataram; 2) kesulitan yang dialami mahasiswa dalam menyusun skripsi dapat menjadi landasan untuk evaluasi kualitas pembelajaran dikelas. Jenis penelitian yang digunakan yaitu penelitian deskriptif kualitatif. Subjek penelitian adalah mahasiswa yang sedang mengerjakan atau mengambil mata kuliah skripsi dalam rentang waktu bulan Oktober 2016 sampai dengan Maret 2017. Kesimpulan dari penelitian ini yaitu: 1) sebaran penelitian mahasiswa dominan pada penelitian kuantitatif dan penelitian R\&D; 2) tema yang diminati (popular) dikalangan mahasiswa yang terkait dengan model penelitian; 3) kesulitan yang dihadapi mahasiswa meliputi penyusunan proposal, instrumen penelitian, pengolahan dan analisis data.

Abstract: The purpose of the research to describe the distribution of undergraduate thesis, that conducted by the Mathematics Education Department students in terms of the research type, theme and also describe they difficulties experienced. The benefit of the research is 1) obtained the distribution of research themes are often or most taken by students of mathematics education department of Muhammadiyah Mataram University, 2)student difficulties in arrange they undergraduate thesis used to evaluate quality of learning. This research is a descriptive qualitative case study. The subjects of the research are Mathematics Education Department students whom taking a thesis course until Ocober 2016 to march 2017. Results of this research are: 1)distribution of the research are dominant in quantitative research and $R \& D$ research; 2) the most popular theme are about leraning model; 3) difficulties face by the student arebout arrange a proposal, research instrument, processing and analysis of data.
\end{abstract}

\section{A. PENDAHULUAN}

Salah satu persyaratan untuk memperoleh gelar sarjana (strata satu), seorang mahasiswa diharuskan mengikuti perkuliahan dan menyelesaikan tugas akhir berupa skripsi. Skripsi adalah karangan ilmiah yang wajib ditulis oleh mahasiswa sebagai bagian dari persyratan akhir pendidikan akademisnya (Yulianto, 2008). Mata kuliah skripsi boleh ditempuh apabila mahasiswa telah menempuh sejumlah SKS tertentu dan lulus mata kuliah metodologi penelitian.

Prestasi belajar siswa yang rendah dan penggunaan metode pembelajaran yang monoton masih menjadi fokus permasalahan yang diteliti oleh mahasiswa. Prestasi belajar yang rendah tentunya dipengaruhi berbagai faktor yang perlu dicarikan solusinya. Demikian, juga dengan metode pembelajaran perlu dicarikan metode, model, pendekatan ataupun strategi pembelajaran yang sesuai dengan karakteristik siswa sehingga dapat meningkatkan prestasi belajar siswa.

Semakin banyak masalah yang timbul, maka semakin banyak pula solusi yang dibutuhkan. Solusi yang ditawarkan tidak bisa serta merta dianggap sebagai solusi yang tepat, solusi perlu melewati serangkaian uji coba yang ilmiah barulah dapat dikatakan solusi yang tepat. Dengan demikian mahasiswa memiliki banyak variasi yang dapat dijadikan masalah penelitian.

Berdasarkan studi pendahuluan yang dilakukan peneliti, sebagian besar mahasiswa terpengaruh oleh penelitian-penelitian yang telah dilakukan mahasiswa pada angkatan sebelum-sebelumnya. Sehingga tema dan penelitian yang dipilih masih monoton atau penelitian yang itu-itu saja. Sedangkan disekolah masih banyak lagi masalah yang muncul dan jenis penelitiannya untuk 
mencari solusinya pun berbeda-beda. Jenis penelitian yang satu belum tentu cocok dengan semua masalah yang ada. Menurut Sugiyono (2010), Jenis penelitian dibagi dalam tiga jenis, penelitian kuantitatif, penelitian kualitatif dan penelitian R\&D. Dan tema penelitian disesuaikan dengan permasalahan disekolah tempat penelitian.

Bagi para mahasiswa, ternyata tugas skripsi merupakan tugas yang tidak ringan. Banyak kesulitan yang dihadapi mahasiswa dalam menyusun skripsi. Apabila kesulitan tersebut tidak dicarikan solusi, dikhawatirkan akan menimbulkan kesalahan berulang pada mahasiswa. Hal ini sejalan dengan pendapat Soedjadi (2007), mengatakan bahwa kesulitan merupakan penyebab terjadinya kesalahan. Proses penyususnan skripsi tidak sama dengan proses belajar didalam kelas. Proses belajar dalam skripsi berlangsung secara individual, berbeda dengan ketika mahasiswa mengikuti mata kuliah lain yang umumnya dilakukan secara klasikal maupun kelompok. Mahasiswa pada awalnya memiliki semangat, motivasi dan minat yang kuat terhadap skripsi, namun keadaan itu akan menurun seiring dengan munculnya berbagai kesulitan yang pada akhirnya menyebabkan mahasiswa tidak dapat menyelesaikan studinya tepat waktu.

Dari uraian tersebut, peneliti merasa perlu untuk melakukan penelitian terkait dengan jenis penelitian, tema popular yang diangkat dalam penelitian mahasiswa dan kesulitan yang dihadapi dalam menyusun skripsi.

Berdasarkan latar belakang tersebut, maka rumusan masalah dari penelitian ini adalah: 1) bagaimanakah sebaran jenis penelitian mahasiswa program studi Pendidikan Matematika Universitas Muhammadiyah Mataram?; 2) apa saja tema popular yang menjadi pilihan mahasiswa?; 3) kesulitan apa yang dihadapi mahasiswa dalam menyelesaikan skripsi mereka?.

Adapun tujuan dari penelitian ini yaitu 1) Mendeskripsikan sebaran jenis penelitian skripsi mahasiswa program studi Pendidikan Matematika Universitas Muhammadiyah Mataram; 2) Mendeskripsikan tema yang popular yang dipilih mahasiswa dalam menyusun skripsi; 3) Mendeskripsikan kesulitan yang dihadapi mahasiswa dalam menyusun skripsi.

Manfaat dari penelitian ini yaitu 1) diperoleh informasi tentang sebaran jenis penelitian dan tema penelitian yang paling seringa tau paling banyak diambil oleh mahasiswa program studi Pendidikan Matematika Universitas Muhammadiyah Mataram; 2) kesulitan yang dialami mahasiswa dalam menyusun skripsi dapat menjadi landasan untuk memperbaiki kualitas pembelajaran dikelas, khususunya mata kuliah yang berkaitan langung dengan penelitian skripsi mahasiswa.

\section{B. METODE PENELITIAN}

Penelitian ini merupakan penelitian deskriptif kualitatif yang menggali sebanyak-banyaknya informasi yang dibutuhkan dalam penelitian. Subjek yang diambil adalah mahasiswa yang sedang mengerjakan atau mengambil mata kuliah skripsi dalam rentang waktu bulan Oktober 2016 sampai dengan Maret 2017.

Penelitian ini bertujuan untuk mengetahui sebaran pilihan mahasiswa terhadap jenis penelitian, tema penelitian dan kesulitan yang mereka hadapi selama proses menyusun skripsi. Setelah dilakukan pengelompokan berdasarkan jenis penelitian, subjek dipilih masing-masing minimal dua orang yang mewakili jenis-jenis penelitian yang dilakukan di prodi Pendidikan Matematika Universitas Muhammadiyah Mataram. Setelah dikelompkan barulah dilakukan wawancara mendalam terhadap masing-masing subjek.

Metode pengumpulan data yang diguakan yaitu metode dokumentasi dan wawancara terbuka. Metode dokumentasi dilakukan untuk mengumpulkan data jenis penelitian yang dilakukan mahasiswa. Sedangkan wawancara terbuka untuk mengetahui atau menggali secara mendalam kecenderungan mahasiswa dalam memilih jenis dan tema penelitian serta kesulitan yang dihadapi dalam menyusun skripsi.

Tekhnik pengecekan keabsahan data dilakuan dengan triangulasi, triangulasi yang digunakan yaitu triangulasi metode (tehnik). Menurut Sugiyono (2008), Triangulasi tehnik berarti peneliti menggunakan tehnik pengumpulan data yang berbeda-beda untuk mendapatkan data dari sumber yang sama.

Tehnik analisis data yang dipergunakan menurut Miles dan Huberman (dalam Sugiyono, 2010) yaitu Reduksi data (data reduction), Pemaparan data (data display)dan Menarik kesimpulan (conclusion).

\section{HASIL DAN PEMBAHASAN}

Hasil penelitian terkait sebaran penelitian skripsi mahasiswa program studi Pendidikan Matematika Universitas Muhammadiyah Mataram yang diperoleh dari dokumentasi dan wawancara sebagai berikut.

\section{Sebaran jenis penelitian mahasiswa}

Jenis penelitian yang dilakukan mahasiswa dapat dikelompokan menjadi tiga jenis, yaitu penelitian kualitatif, penelitian kuantitatif dan penelitian R\&D. Penelitian pada program studi Pendidikan Matematika Universitas Muhammadiyah Mataram untuk saat ini hanya menawarkan ketiga jenis penelitian tersebut kepada mahasiswa. Sebaran jenis penelitian ini perlu untuk diketahui sebagai dasar pertimbangan menentukan pembagian judul yang merata dan bervariasi bagi mahasiswa. Sehingga tidak hanya satu atau dua penelitian saja yang memiliki banyak peminat, tetapi semuanya dapat dibagi secara merata. Atau bahkan untuk memunddculkan ide-ide penelitian baru yang sebelumnya belum pernah diteliti oleh mahasiswa. Berdasarkan dokumen pembagian judul skripsi mahasiswa yang ada di program studi Pendidikan 
Matematika Universitas Muhammadiyah Mataram, diperoleh data sebagai berikut.

TABEL 1

JUMLAH PENELITIAN BERDASARKAN JENISNYA

\begin{tabular}{clcc}
\hline No & Jenis Penelitian & $\begin{array}{c}\text { Jumlah } \\
\text { mahasisa }\end{array}$ & persentase \\
\hline 1 & Penelitian Kuantitatif & 7 & $38,9 \%$ \\
2 & Penelitian Kualitatif & 4 & $22,2 \%$ \\
3 & Penelitian R\&D & 7 & $38,9 \%$ \\
\hline
\end{tabular}

Dari data yang diperoleh, jelas bahwa penelitian kuantitatif dan pengembangan memiliki banyak peminat. Hal ini terlihat berdasarkan jumlah mahasiswa yang memilih jenis penelitian tersebut lebih banyak dibanding penelitian kualitatif dengan persentase keduanya sama-sama sebesar 38,9\%, sedangkan kualitatif hanya 22,2 \% dari keseluruhan mahasiswa yang sedang menyusun skripsi.

Berdasarkan wawancara dengan mahasiswa, hal ini diakibatkan oleh terbatasnya pengetahuan mahasiswa tentang penelitian kualitatif dan masih sangat sedikit penelitian-penelitian kualitatif yang mereka temui diperpustakaan. Selain itu, ada kebingungan mahasiswa dalam menentukan tema apa yang dapat diangkat untuk dijadikan penelitian kualitatif. Penelitian kuantitatif juga lebih popular dikalangan mahasiswa, baik program studi pendidikan matematika maupun program studi lain, sehingga mahasiswa terpengaruh untuk ikut memilih penelitian tersebut.

Penelitian R\&D juga memiliki jumlah peminat yang sama dengan penelitian kuantitatif. Berdasarkan hasil wawancara dengan mahasiswa. Ada yang beranggapan penelitian tersebut lebih menarik dan lebih mudah dari penelitian lainnya karena merasa tidak mampu mendeskripsikan atau menggambarkan penelittian mereka dengan baik. Namun, ada pula mahasiswa yang mengaku terpaksa memilih penelitian tersebut karena rekomendasi dosen mereka.

\section{Tema Penelitian}

Tema yang sering diambil oleh mahasiswa dalam skripsi yang mereka susun dpat dilihat dalam tabel berikut.

TABEL 2

TEMA YANG POPULAR

\begin{tabular}{clcc}
\hline No & \multicolumn{1}{c}{ Tema } & $\begin{array}{c}\text { Jumlah } \\
\text { Mahasiswa }\end{array}$ & persentase \\
\hline 1 & $\begin{array}{l}\text { Model } \\
\text { Pembelajaran }\end{array}$ & 7 & $38,9 \%$ \\
2 & $\begin{array}{l}\text { Pendekatan } \\
\text { Pembelajaran }\end{array}$ & 3 & $16,6 \%$ \\
3 & $\begin{array}{l}\text { Metode } \\
\text { Pembelajaran }\end{array}$ & $\begin{array}{l}\text { Strategi } \\
\text { Pembelajaran }\end{array}$ & $\begin{array}{l}\text { Kemampuan } \\
\text { Kognitif }\end{array}$ \\
6 & Gender & 3 & $5,5 \%$ \\
\hline
\end{tabular}

Berdasarkan tabel diperoleh tema yang terpopular dikalangan mahasiswa yaitu tentang model pembelajaran dengan persentase sebesar $38,9 \%$, baru kemudian berturut-turut pendekatan pembelajaran sebesar $16,6 \%$, strategi pembelajaran sebesar 16,6 \%, kemampuan kognitif sebesar 16,6 \%, metode pembelajaran sebesar 5,5 \%dan gender sebesar $5,5 \%$.

Sedangkan berdasarkan wawancara, hal ini diakibatkan karena, mahasiswa lebih paham mengenai model pembelajaran dibanding dengan tema yang lain. Sebagian mahasiswa juga ada yang belum mampu membedakan model, metode, pendekatan dan strategi pembelajaran. Selain itu, mahasiswa juga terpengaruh dengan penelitianpenelitian sebelumnya yang banyak mengambil tema tentang model pembelajaran. Serta, referensi tentang model pembelajaran lebih mudah dijumpai dibanding buku referensi penunjang yang membahas strategi dan pendekatan pembelajaran.

\section{Kesulitan yang dihadapi dalam penelitian}

Menyusun sebuah karya ilmiah bagi sebagian orang yang sebelumnya pernah mempelajarinya bukanlah hal yang sulit, namun lain halnya bagi mahasiswa yang sebagian besar belum pernah melihat atau bahkan membaca karya ilmiah yang berkaitan dengan skripsi. Hal ini menjadikan terkadang menimbulkan kesulitan bagi sebagian besar mahasiswa. Pada umumnya perjalanan studi mahasiswa menjadi tersendat-sendat atau terhambat ketika menyusun skripsi.

Berdasarkan hasil wawancara dengan mahasiswa, berbagai kesulitan dikemukakan oleh mahasiswa mulai dari masalah ekonomi hingga yang berkaitan dengan dosen pembimbing. Untuk lebih jelasnya dapat kita lihat dalam table berikut.

TABEL 3

KESULITAN MENYUSUN SKRIPSI YANG DIALAMI MAHASISWA

\begin{tabular}{|c|c|c|}
\hline No & Kesulitan & Solusi \\
\hline 1 & $\begin{array}{l}\text { Terkendala biaya } \\
\text { pendaftaran seminar } \\
\text { dan ujian, serta } \\
\text { konsumsi untuk } \\
\text { peserta semiar }\end{array}$ & $\begin{array}{ll}\text { - } & \text { Bicarakan } \\
\text { dengan orang } \\
\text { tua dan } \\
\text { keluarga }\end{array}$ \\
\hline 2 & $\begin{array}{l}\text { Kesulitan } \\
\text { menemukan } \\
\text { masalah } \\
\text { membuat } \\
\text { penelitian }\end{array}$ & $\begin{array}{l}\text { - } \quad \text { Perlu lebih } \\
\text { memahami apa } \\
\text { yang dilakukan } \\
\text { dalam } \\
\text { observasi } \\
\text { penelitian serta } \\
\text { konsultasi pada } \\
\text { dosen }\end{array}$ \\
\hline 3 & $\begin{array}{l}\text { Dosen pembimbing } \\
\text { yang sulit ditemui }\end{array}$ & $\begin{array}{l}\text { Komunikasi } \\
\text { dengan dosen, } \\
\text { rekan } \\
\text { mahasiswa } \\
\text { yang memiliki } \\
\text { pembimbing } \\
\text { sama }\end{array}$ \\
\hline 4 & $\begin{array}{l}\text { Kesulitan merangkai } \\
\text { kata-kata untuk }\end{array}$ & $\begin{array}{ll}\text { - } & \text { Perbayak } \\
\text { membaca karya }\end{array}$ \\
\hline
\end{tabular}


mulai menulis

5 Membedakan penelitian yang satu dengan yang lain
6

Mahasiswa
kebingungan
menentukan analisis
statistik yang
digunakan saat
mengolah dan
menganalisis data

menganalisis data
7 Menentukan instrumen penelitian dan perangkat pembelajaran yang digunakan ilmiah ataupun buku-buku referensi yang relevan Perbanyak membca sumber-sumber yang valid dan relevan.

- Memperhatikan dengan baik saat perkulihan mata kuliah Metodologi Penelitian

- Perbanyak membaca yang valid dan relevan.

- Memperhatikan dengan baik saat perkulihan mata kuliah statistik metodologi penelitian Banyak membaca dan diskusi dengan dosen ataupun Memperhatikan ketika dosen menjelaskan pada saat ada penjelaan tentang keduanya (metodologi penenlitian). sumber-sumber penelitian dan teman sejawat.

menemukan masalah dan membuat judul penelitian. Mahasiswa banyak yang mengalami kebingungan saat akan mengajukan judul skripsi. Bingung tentang judul apa yang akan diambilnya, sedangkan untuk mengkonsep sebuah judul diperlukan masalah terlebih dahulu; 3) dosen pembimbing yang sulit ditemui. Keluhan ini banyak diungkapkan oleh mahasiswa, yang ingin cepat menyelesaikan skripsi akan tetapi dosen pembimbing ingin proses pembimbingan dilakukan sesuai prosedur dan tidak terburu-buru. Bagaimanapun kegiatan dosen pembimbing tidak hanya melayani mahasiswa bimbingannya, tetapi banyak tugas lain yang harus dikerjakan juga dalam waktu bersamaan, inilah yang sulit diterima mahasiswa yang ingin cepat selesai; 4) kesulitan merangkai kata-kata. Perlu banyak membaca untuk memperbanyak kosakata dalam menulis ilmiah; 5) membedakan penelitian yang satu dengan yang lain. Di mata kuliah metodologi penelitian sudah dijelaskan jenis-jenis penelitian, sistematika, perbedaan penelitian yang satu dengan lainnya, langkah menyusun setiap bagian dari skripsi dan masih banyak lagi; 6) Bingung menentukan analisis statistik dalam mengolah dan analisis data. Hal ini bisa jadi akibat dari mahasiswa yang tidak memperhatikan penjelaan dosen pada saat materi tersebut diajarkan dan kurang membaca, hanya mengandalkan perkuliahan saja; 7) menentukan instrument penelitian dan perangkat pembelajaran. Mahasiswa terkadang bingung membedakan mana yang disebut instrumen penelitian dan perangkat pembelajaran.

Secara umum kesulitan mahasiswa dalam mengerjakan skripsi dapat dikelompokkan menjadi beberapa bagian. 1) kesulitan dalam menyusun rancangan penelitian (proposal penelitian); 2) menyusun instrument penelitian; dan 3) pengolahan dan analisis data penelitian.

Dengan demikian dapat disimpulkan bahwa kesulitan mengerjakan skripsi tidak hanya berasal dari tulisan yang terdapat dalam skripsi tersebut, tetapi jg dari dalam diri Mahasiswa, dosen dan lingkungannya. Kesulitan yang dihadapi mahasiswa sebagai berikut. 1) Terkendala biaya pendaftaran seminar dan ujian, serta konsumsi untuk peserta semiar. Beberapa mahasiswa yang sedang menyusun skripsi merupakan mahasiswa mandiri, yang membiayai sendiri perkuliahannya sehingga merasa sedikit berat untuk menanggung biaya itu semua seorang diri. Untuk itu perlu dilakukan diskusi dengan orang tua atau pun keluarga untuk mengatasi hal tersebut. Karena, mau tidak mau mahasiswa tetap harus menuntaskan kewajibannya untuk melunasi biaya perkuliahan; 2) kesulitan

\section{SIMPULAN DAN SARAN}

Adapun simpulan dari penelitian ini sebagai berikut. 1) sebaran penelitian mahasiswa dominan pada penelitian kuantitatif dan penelitian R\&D; 2) tema yang diminati (popular) dikalangan mahasiswa yang terkait dengan model penelitian; 3) kesulitan yang dihadapi mahasiswa meliputi penyusunan proposal, instrumen penelitian, pengolahan dan analisis data.

Sedangkan saran dari peneliti yaitu: perlu adanya penelitian lanjutan untuk merancang sebuah pembelajaran atau model yang efektif untuk meminimalkan kesulitan yang dihadapi mahasiswa dalam menyelesaikan skripsi, khususnya mata kuliah metodologi penelitian.

\section{UCAPAN TERIMA KASIH}

Terima kasih kepada semua pihak yang telah mendukung sehingga penelitian ini dapat dilaksanakan, Bapak Dekan FKIP UM Mataram dan Bapak Ibu Wakil Dekan, Kaprodi Pendidikan Matematika, dan terutama mahasiswa yang telah memluangkan waktunya untuk menjawab pertanyaan yang diberikan peneliti. 


\section{DAFTAR RUJUKAN}

Soedjadi, Masalah Kontekstual Sebagai Batu Sendi Matematika Sekolah. Departemen Pendidikan Nasional, Pusat Sains dan Matematika Sekolah: Universitas Negeri Surabaya, 2007.

Sugiyono, Memahami Penelitian Kualitatif. Bandung, Alfabeta, 2008.

Metode Penelitian Kuantitatif, Kualitatif, dan R\&D. Bandung, Alfabeta, 2010.

Yulianto, Aries, Kamus Besar Bahaa Indonesia Pusat Bahasa (4th nd). Jakarta, Gramedia Pustaka Utama, 2008. 